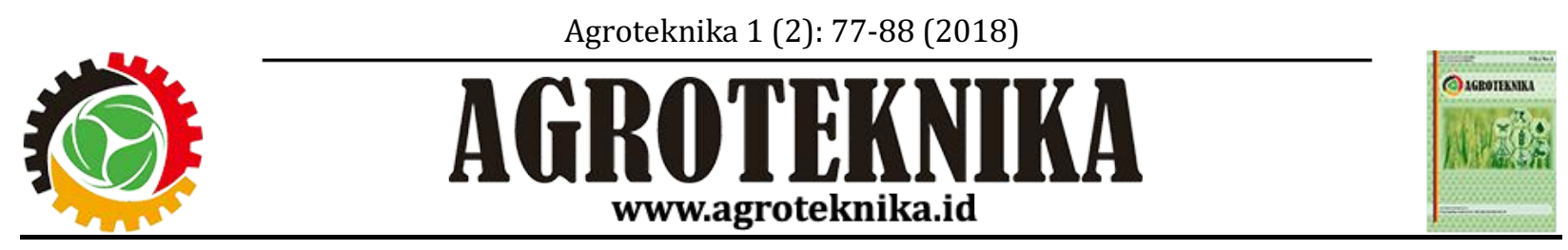

\title{
Rancang Bangun Mesin Pengupas Tempurung Kelapa
}

\section{Design of Coconut Shell Paring Machine}

Gaib Prayogi, Robby Wahyudy, Satria Yogaswara*, Teguh Primayuldi

Program Studi Mesin dan Peralatan Pertanian, Politeknik Pertanian Negeri Payakumbuh

\author{
*Penulis Korespondensi \\ Email : satriayogaswara95@gmail.com
}

\begin{abstract}
Abstrak. Kelapa banyak dibudidayakan dan dimanfaatkan oleh masyarakat untuk berbagai keperluan dan buah kelapa merupakan bagian yang paling sering dimanfaatkan. Buah kelapa diolah menjadi berbagai jenis makanan, minuman, masakan dan bahan baku pembuatan minyak (kopra). Untuk menghasilkan kopra dan santan, buah kelapa dipisah terlebih dahulu antara daging buah dan tempurung. Untuk produksi santan, pengupasan tempurung ini berguna untuk menjaga kemurnian santan. Pemarutan daging kelapa beserta tempurung secara manual atau mekanik dinilai kurang efektif karena cara pemarutan ini membuat tempurung juga ikut terparut sehingga hal ini mempengaruhi kualitas santan. Pengupasan tempurung kelapa dengan menggunakan mesin pengupas membutuhkan waktu rata-rata 205 detik per kelapa. Sedangkan pengupasan satu buah secara manual menghabiskan waktu sekitar 528 detik. Kapasitas pengupasan kelapa melalui penggunaan mesin dan manual adalah 17 buah kelapa/jam dan 8 buah/ jam. Hal ini membuktikan bahwa kinerja mesin 2 kali lebih cepat daripada kinerja pengupasan secara manual. Hasil analisa ekonomi mesin pengupas tempurung kelapa diperoleh biaya tetap sebesar Rp 748.696/tahun, biaya tidak tetap sebesar Rp 11.147,87 /jam, biaya pokok untuk pengupasan satu buah kelapa adalah Rp 674 dan Break Event Point adalah 5.190 buah per tahun.
\end{abstract}

Kata kunci : kelapa, mesin pengupas tempurung

Abstract. Coconut is cultivated and utilized by the community for various purposes and coconuts are the most commonly used parts. Coconut fruit is used as food, drink, cooking and raw material for making oil (copra). To produce copra and coconut milk, the coconut fruit is separated first for getting the flesh and the shell. For coconut milk production, shell shelling is helpful for maintaining the purity of coconut milk. Manual coconut meat and shells separation are considered to be less effective because the method of coating makes the shell also shredded so that this affects the quality of the coconut milk. Stripping the coconut shell using a peeler requires an average of 205 seconds per coconut. While manual stripping takes around 528 seconds. The capacity of stripping coconut through the use of machines and manuals is 17 coconuts/hour and 8 pieces/hour. This machine increase performance to 2 times faster than manual performance. The results of the economic analysis of coconut shell peeler machine are fixed costs Rp. 748,696 / year, the nonfixed costs are Rp. 11,147.87 / hour, the basic costs for stripping one coconut are Rp. 674 and Break Event Point is 5,190 pieces per year.

Keywords: coconut, shell, paring machine 


\section{Pendahuluan}

Tumbuhan kelapa (Cocos nucifera $L$ ) merupakan komoditi ekspor yang dapat tumbuh di sepanjang pesisir pantai, dataran tinggi serta lereng gunung. Buah kelapa terdiri dari 4 bagian yaitu 35\% serabut, 12\% tempurung, 28\% daging kelapa, dan 25\% air (Woodroof, 1978). Kelapa dibudidayakan dan dimanfaatkan oleh masyarakat untuk berbagai keperluan. Buah kelapa merupakan bagian yang paling sering dimanfaatkan dan digunakan sebagai komponen pembuatan makanan, minuman, masakan dan bahan baku pembuatan minyak (kopra). Menurut Woodrof, (1978) dan Djatmiko, (1983), bagian terpenting dari buah kelapa yang digunakan sebagai bahan pangan adalah daging buahnya karena merupakan sumber lemak nabati.

Pengupasan tempurung kelapa bertujuan untuk memisahkan daging kelapa dan tempurung. Menurut Mahmud dan Fery (2005), daging buah kelapa merupakan komponen utama yang dapat diolah menjadi produk bernilai ekonomi tinggi. Salah satu hasil olahan dari daging buah kelapa ini adalah coconut milk atau santan kelapa. Cristianti dan Prakosa (2009) menyebutkan bahwa santan adalah cairan yang diperoleh dengan melakukan pemerasan pada daging buah kelapa parut. Santan merupakan bahan makanan yang dipergunakan untuk mengolah berbagai jenis masakan seperti daging, ikan, ayam, pembuatan kue-kue, es krim, gula-gula dan lain-lain.

Pengupasan tempurung kelapa tidak ditujukan untuk pembuatan santan kelapa saja. Kelapa hasil pengupasan juga banyak digunakan untuk kopra. Kopra merupakan buah kelapa yang menjadi bahan baku minyak (Warisno, 2003). Palungkun (2001) mengatakan bahwa dalam skala industri besar dan menengah, minyak kelapa umumnya diolah dari bahan baku kopra. Kualitas minyak kelapa yang dihasilkan sangat ditentukan oleh kualitas kopra. Kopra adalah daging buah kelapa segar yang dikeringkan. Kopra dapat digolongkan menjadi dua jenis kopra yaitu kopra hitam dan putih (Sulaman \& Rusyadi, 2013). Kopra hitam biasanya digunakan untuk bahan baku minyak kelapa (coconut oil). Pengeringan untuk mendapatkan kopra hitam maksimal 2 hari dengan temperatur rata-rata $60^{\circ} \mathrm{C}$. Kopra putih biasanya digunakan untuk keperluan kosmetik dll. Proses pengeringan kopra putih biasanya berlangsung selama $2 / 3$ hari dengan temperatur rata-rata $60^{\circ} \mathrm{C}$.

Pengupasan tempurung kelapa masih banyak dilakukan menggunakan alat manual. Salah satu alat manual yang digunakan memiliki bentuk seperti sebuah parang dengan bagian ujung melengkung yang di pulau Jawa dikenal dengan nama Cungkilan. Penggunaan alat ini masih belum efektif dari segi waktu dan tenaga. Butuh waktu antara 3-5 menit untuk mengupas tempurung kelapa. Mesin pengupas tempurung kelapa dapt membut pekerjaan pengupasan 
tempurung kelapa mejadi lebih efektif. Dari uji kinerja yang telah dilakukan, kapasitas kerja mesin pengupas tempurung kelapa dua kali lebih besar dari pada cara manual.

Masyarakat provinsi Sumatera Barat khususnya Kabupaten Lima Puluh Kota dan Kotamadya Payakumbuh merupakan salah satu konsumen santan kelapa murni yang potensial. Karena hampir di setiap masakan menggunakan santan kelapa sebagai bumbu dapur. Selain itu, makanan khas masyarakat Sumatera Barat yang terkenal dengan cita rasa dan harga jual tinggi sebahagian besar menggunakan santan dengan kemurnian yang tinggi. Oleh karena itu, dengan adanya mesin pengupas tempurung kelapa, masyarakat Sumatera Barat dapat terbantu dalam pengolahan santan murni. Masyarakat Kabupaten Kampar provinsi Riau juga sangat membutuhkan alat pengupas tempurung kelapa. Hal ini karena, masyarakat wilayah Kampar banyak yang menekuni pengolahan kopra sebagai salah satu mata pencaharian.

\section{Bahan dan Metode}

\section{Alat dan Bahan}

Alat-alat yang digunakan pada pembuatan rancang bangun mesin pengupas tempurung kelapa dapat dilihat pada Tabel 1.

Tabel 1. Alat - Alat yang digunakan

\begin{tabular}{clll}
\hline No. & \multicolumn{1}{c}{ Jenis Alat } & \multicolumn{1}{c}{ Spesifikasi } & \multicolumn{1}{c}{ Jumlah } \\
\hline 1 & Mesin las listrik & Bx6-250 & 1 unit \\
2 & Mesin gerinda tangan & Makita a24sbf & 1 unit \\
3 & Mesin gerinda potong & 2000 watt & 1 unit \\
4 & Mesin bor & $477 \times 581 \mathrm{~mm}$ & 1 unit \\
5 & Rol siku & Aluminum m2 & 1 buah \\
6 & Jangka sorong & Mitutoyo & 1 buah \\
7 & Gerinda duduk & Kw07-74 & 1 unit \\
8 & Meteran & Lever lock $5 \mathrm{~m}$ & 1 buah \\
9 & Palu & Tk 610 & 1 buah \\
10 & Mesin bubut & Amc 36/1000 & 1 unit \\
11 & Mesin gergaji potong & $4327 \mathrm{~m} 2$ & 1 unit \\
12 & Perlengkapan safety & SNI & 1 set \\
\hline
\end{tabular}

Bahan-bahan yang digunakan pada pembuatan rancang bangun mesin pengupas tempurung kelapa dapat dilihat pada Tabel 2.

Tabel 2. Bahan-bahan yang digunakan

\begin{tabular}{clll}
\hline No. & \multicolumn{1}{c}{ Bahan } & \multicolumn{1}{c}{ Spesifikasi } & \multicolumn{1}{c}{ Jumlah } \\
\hline 1 & Motor listrik & $3 / 4 \mathrm{HP}, 1400 \mathrm{Rpm}$ & 1 Buah \\
2 & Besi siku & $30 \times 30 \times 3 \mathrm{~mm}$ & 2 Batang \\
3 & Besi poros & $1 \mathrm{Inchi}$ & $1 / 4$ batang \\
4 & Bearing & 6201 & 2 Buah \\
5 & Baut dan mur & $\mathrm{M} 10 \times 2.5 \mathrm{~mm}$ & 10 Buah \\
6 & Baut dan mur & $\mathrm{M} 12 \times 2.5 \mathrm{~mm}$ & 7 Buah
\end{tabular}




\begin{tabular}{clll}
7 & Elektroda & N.K 26 & 1 Kotak \\
8 & Rantai dan gear & $14 \times 14 \mathrm{~T} \mathrm{60L}$ & 1 set \\
9 & Pulley dan v-belt & $\varnothing 10$ dan Ø 4 Inchi & 1 set \\
10 & Besi u & $65 \times 42 \times 5.5 \mathrm{~mm}$ & $1 / 4$ Batang \\
11 & Roda gigi lurus & Gear 35T & 1 Pasang \\
12 & Speed reducer & Ratio 1:30 & 1 Buah \\
13 & Amplas & P220 & 1 Rol \\
14 & Cat & Avitex 304, Hijau & 1 Kaleng \\
15 & Kuas & Kuas Eternal & 1 buah \\
\hline
\end{tabular}

\section{Rancangan Alat}

Rancangan fungsional dan rancangan struktural mesin pengupas tempurung kelapa adalah sebagai berikut :

\section{Kerangka}

Kerangka merupakan bagian utama yang menopang semua komponen alat dan mesin. Kerangka mesin terbuat dari besi siku yang disambungkan dengan sambungan pengelasan. Kerangka memiliki ukuran panjang $60 \mathrm{~cm}$, lebar $50 \mathrm{~cm}$, dan tinggi $116 \mathrm{~cm}$. Kerangka dapat dilihat pada Gambar 1.

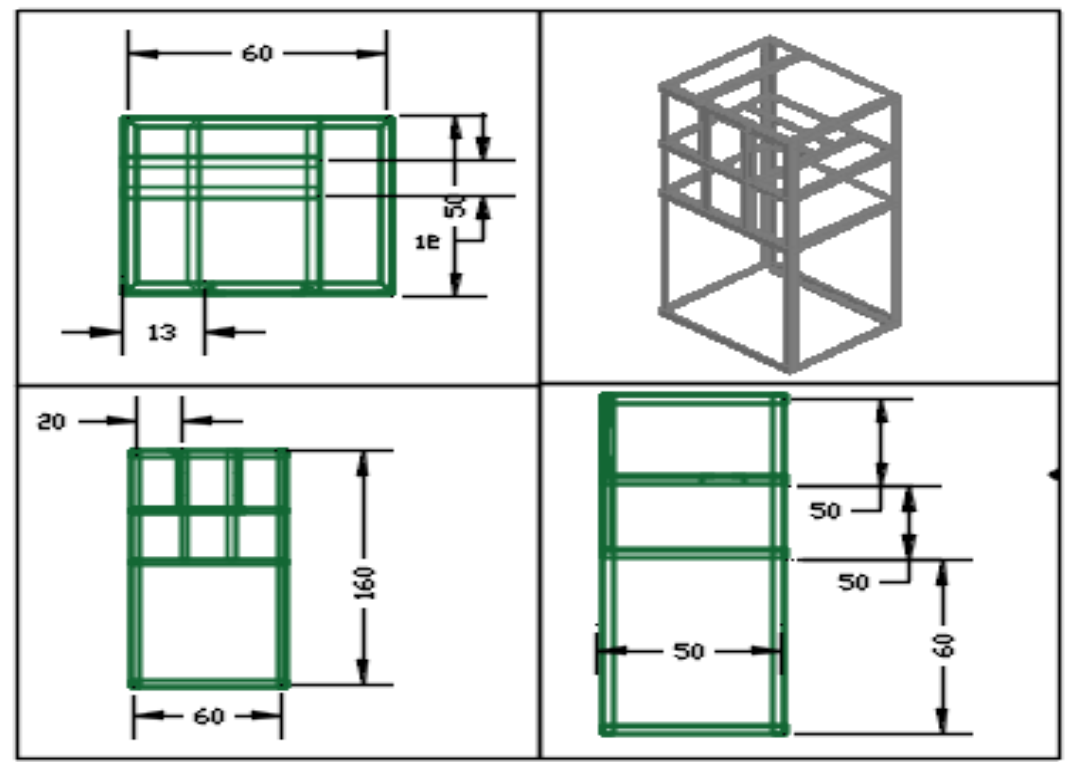

Gambar 1. Kerangka

Mata pisau

Mata pisau berfungsi untuk mengupas tempurung kelapa dengan daging buah. Pisau terbuat dari Baja Olah Cepat (HSS) yang disambungkan dengan pengelasan pada besi poros. Baja Olah Cepat yang digunakan berdiameter 1 inchi dan panjang $150 \mathrm{~mm}$. Mata pendorong / penekan dibuat dari gear Honda GL 45T sebanyak 2 buah. Gear Honda 45T terbuat dari besi baja dan diubah menjadi gear 22T berdiameter $190 \mathrm{~mm}$. Mata pisau dapat dilihat pada Gambar 2. 


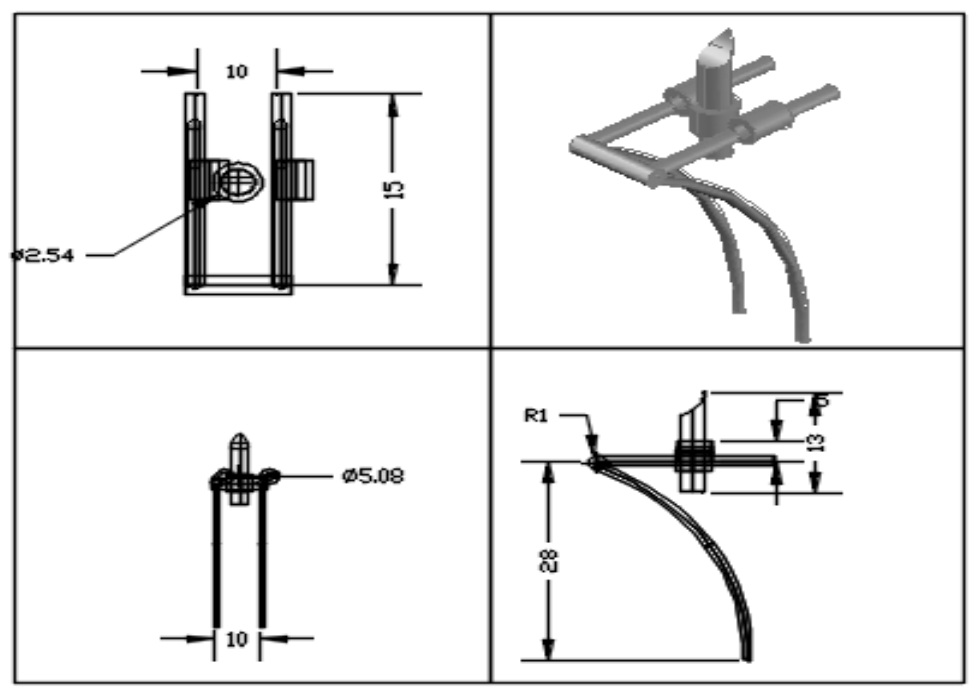

Gambar 2. Mata pisau

Pulley

Pulley yang digunakan berdiameter 10 inchi dan 4 inchi. Jarak pemasangan kedua pulley yaitu $32 \mathrm{~cm}$. Pulley dapat dilihat pada Gambar 3.

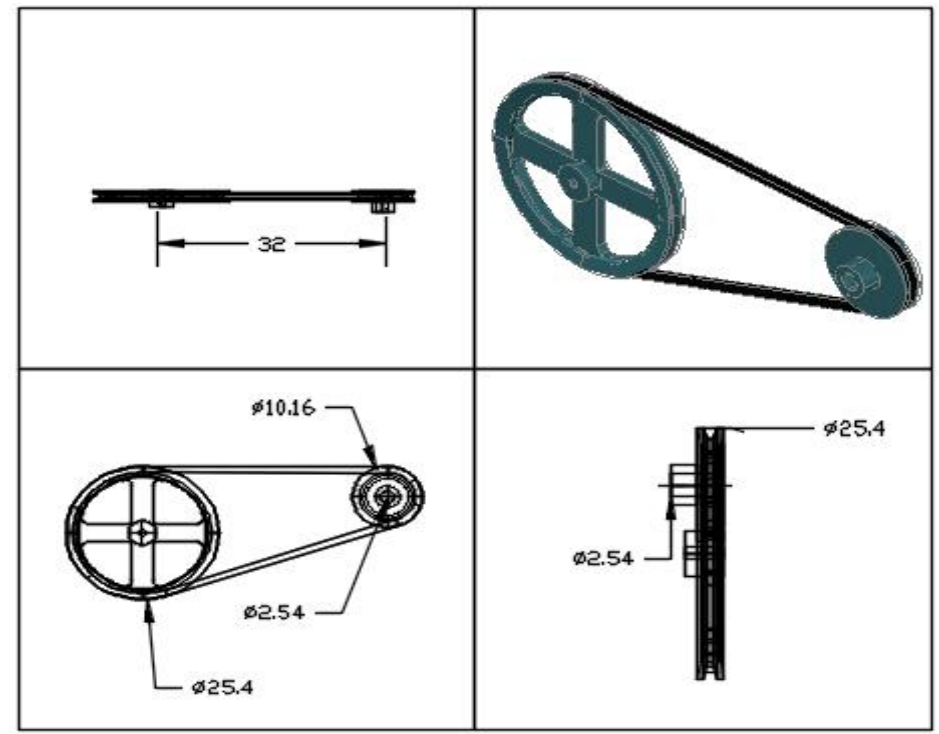

Gambar 3. Pulley

\section{Gear dan rantai}

Rantai dan gear digunakan untuk penggerak poros gear pendorong. Gear yang digunakan berjumlah 2 buah memiliki diameter 3 inchi. Gear dan rantai dapat dilihat pada Gambar 4. 


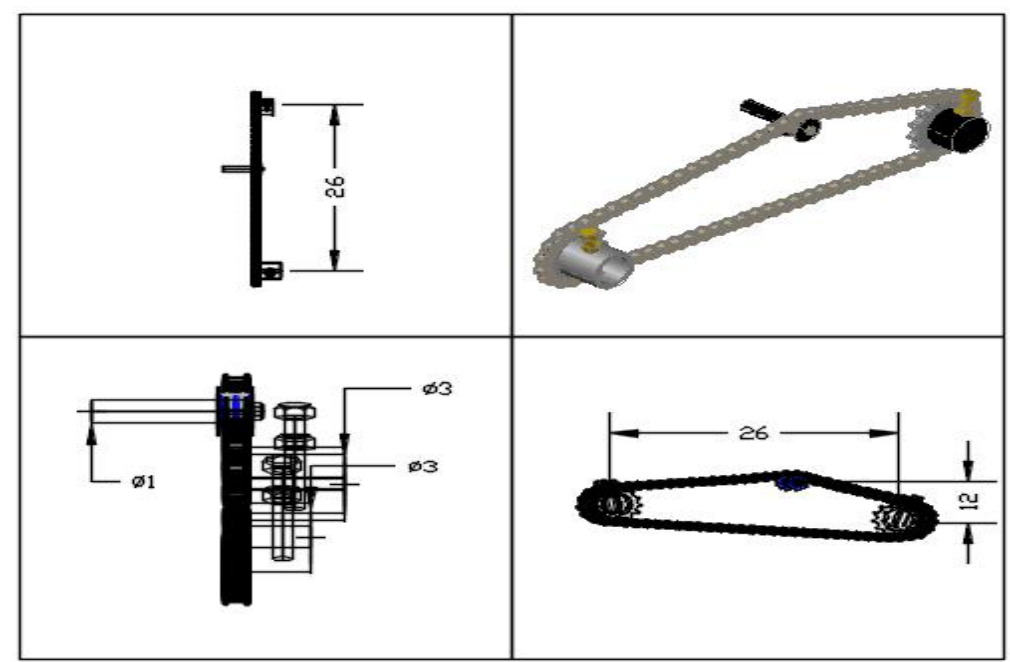

Gambar 4. Gear dan rantai

\section{Poros}

Poros yang digunakan berdiameter 1 inchi dengan panjang $28 \mathrm{~cm}$. Poros dapat dilihat pada Gambar 5.

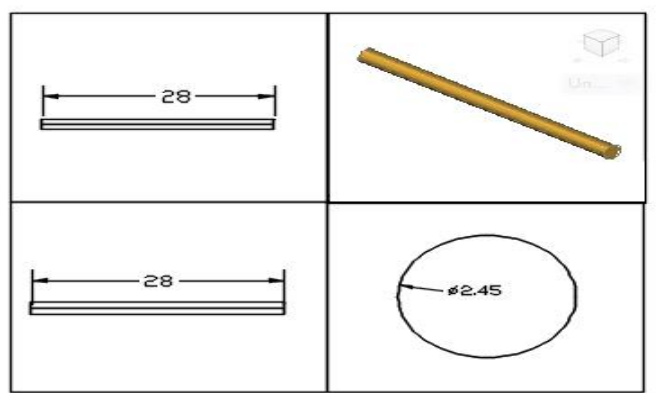

Gambar 5. Poros

\section{Gear pendorong}

Gear pendorong berfungsi untuk menekan tempurung kelapa ke arah pisau sehingga pisau dapat mengupas tempurung kelapa. Gear pendorong terdiri dari 2 buah gear yang berdiameter 7,48 cm. Gear pendorong dapat dilihat pada Gambar 6 .

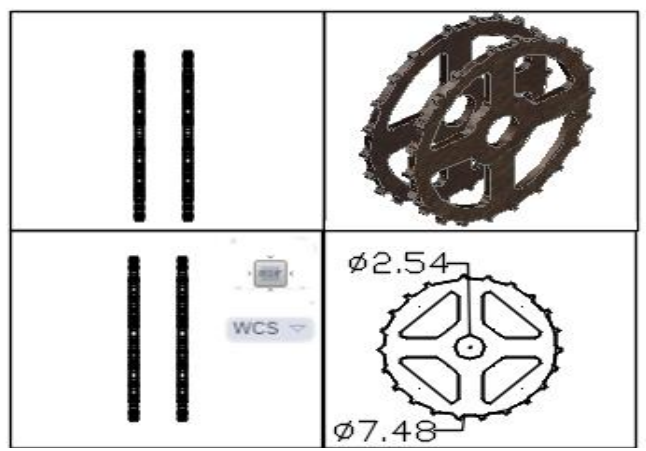

Gambar 6. Gear pendorong

Motor penggerak

Motor penggerak digunakan sebagai sumber tenaga pada mesin. 


\section{Speed reducer}

Speed reducer berfungsi untuk mereduksi putaran dari motor listrik dengan perbandingan tertentu sehingga dapat memberikan daya dan torsi untuk penekanan terhadap gear.

\section{Bearing UCP}

Bearing digunakan untuk kedudukan poros saat berputar.

Desain perakitan semua komponen dapat dilihat pada Gambar 7.

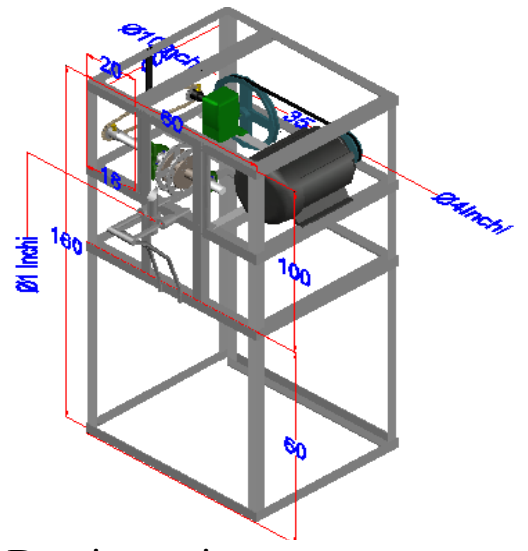

Gambar 7. Desain mesin pengupas tempurung kelapa

\section{Metode Pelaksanaan}

Metode pelaksanaan pembuatan mesin pengupas tempurung kelapa dapat dilihat pada Gambar 8 .

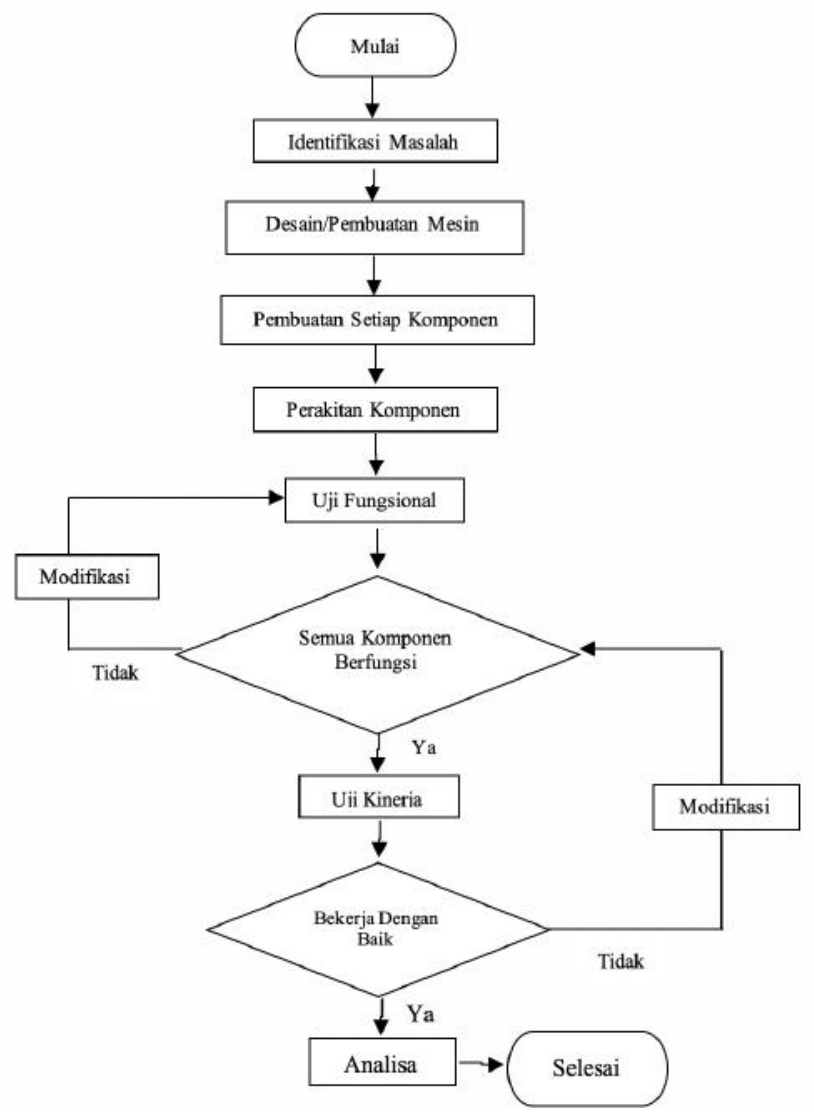

Gambar 9. Diagram alir pembuatan mesin pengupas tempurung kelapa 


\section{Hasil dan Pembahasan}

Mesin pengupas sabut kelapa dan bagian-bagiannya dapat dilihat pada Gambar 10.

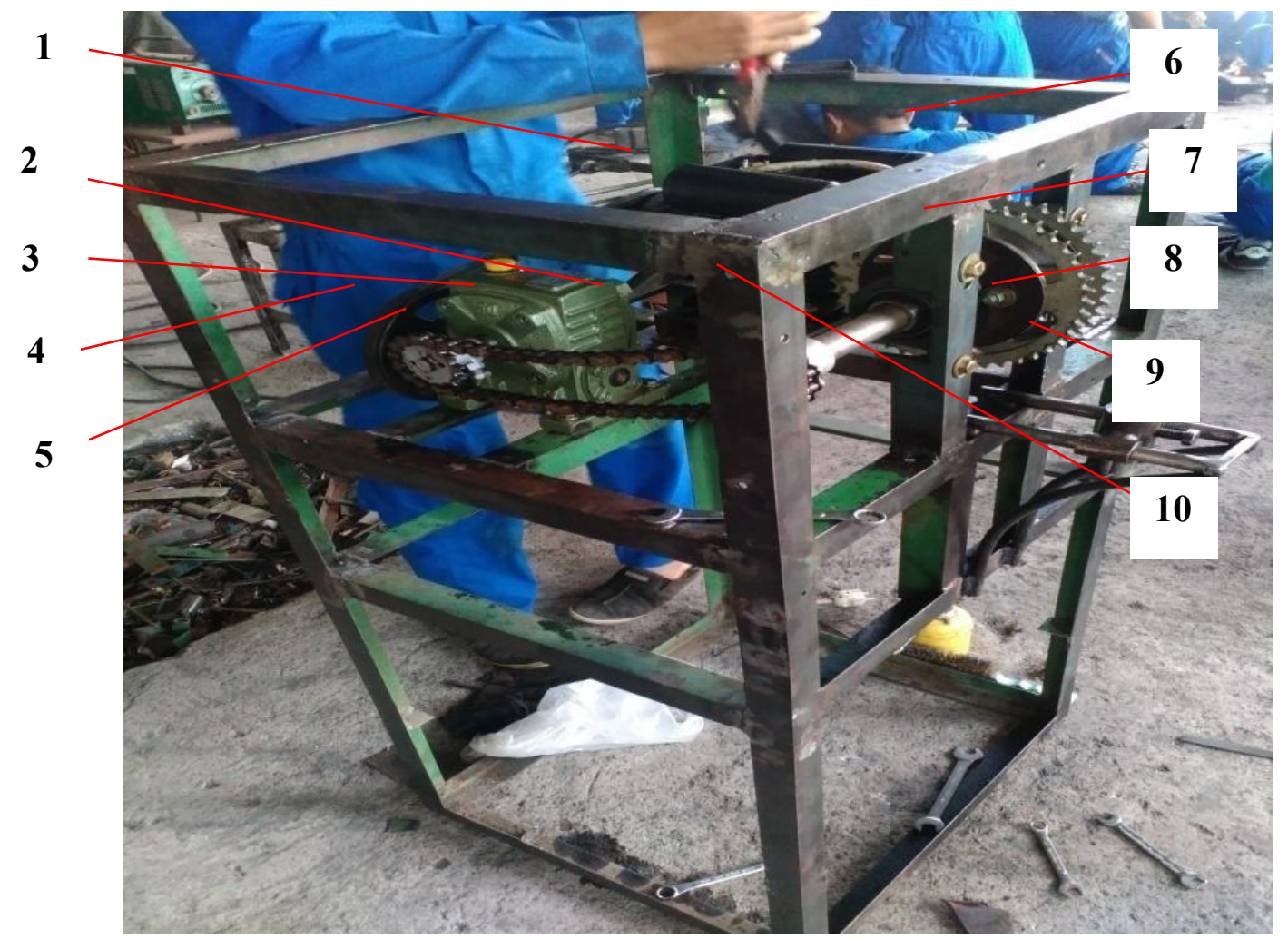

Gambar 10. Hasil perakitan komponen mesin

Keterangan Gambar:

1. Motor listrik

2. Penahan rantai

3. Speed reducer

4. Belt and pulley

5. Rantai dan gear
6. Kerangka

7. Gir pendorong

8. Mata pisau

9. Dudukan mata pisau

10. Poros

Proses kerja mesin pemisah tempurung kelapa adalah mata gear pendorong digerakkan menggunakan motor listrik $3 / 4$ HP. Sebelumnya putaran motor disalurkan menuju speed reducer dengan ratio $30: 1$. Putaran motor berlawanan arah jarum jam kemudian buah kelapa yang sudah di kupas kulitnya ditempelkan diantara pisau pengupas dan gear pendorong menggunakan tangan operator dan diputar secara perlahan-lahan.

Spesifikasi mesin pengupas tempurung kelapa dapat dilihat pada Tabel 3.

Tabel 3. Spesifikasi dan ukuran bagian - bagian dari mesin pengupas tempurung.

\begin{tabular}{cll}
\hline No. & \multicolumn{1}{c}{ Keterangan Alat } & \multicolumn{1}{c}{ Ukuran/tipe } \\
\hline 1 & Jenis alat & Semi mekanis \\
2 & Tinggi alat & $116 \mathrm{~cm}$ \\
3 & Lebar alat & $50 \mathrm{~cm}$ \\
4 & Panjang alat & $60 \mathrm{~cm}$ \\
5 & Berat alat & $35 \mathrm{~kg}$ \\
6 & Ukuran gear pendorong & $19 \mathrm{~cm}$
\end{tabular}




\begin{tabular}{cll}
7 & Jumlah gear pendorong & 2 buah \\
8 & Daya motor & $3 / 4 \mathrm{HP}$ \\
9 & Bahan mata pisau & HSS \\
10 & Kecepatan putaran gear pendorong & 19 RPM \\
\hline
\end{tabular}

\section{Pengujian Alat}

Dari uji kinerja alat yang telah dilakukan, didapat hasil yang dapat dilihat pada Tabel 4 dan Tabel 5.

Tabel 4. Data hasil pengujian pengupasan tempurung kelapa menggunakan mesin

\begin{tabular}{ccccc}
\hline No. & Pengujian & Jumlah (buah) & Waktu (Detik) & Kapasitas (buah/jam) \\
\hline 1 & I & 1 & 220 & 17 \\
2 & II & 1 & 205 & 17 \\
3 & III & 1 & 190 & 17 \\
\hline \multicolumn{2}{r}{ Rata - rata } & 205 detik & 17 buah/jam \\
\hline
\end{tabular}

Tabel 5. Data percobaan pengupasan tempurung kelapa secara manual

\begin{tabular}{ccccc}
\hline No. & Pengujian & Jumlah (buah) & Waktu (Detik) & Kapasitas (buah/jam) \\
\hline 1 & I & 1 & 520 & 8 \\
2 & II & 1 & 525 & 8 \\
3 & III & 1 & 540 & 8 \\
\hline \multicolumn{2}{r}{ Rata - rata } & 528 detik & 8 buah/jam \\
\hline
\end{tabular}

\section{Uji Kinerja Alat}

Dari uji kinerja yang dilakukan terhadap mesin pengupas tempurung kelapa dapat dihitung :

Kapasitas pengupasan

Yaitu jumlah keseluruhan kelapa yang terkupas, baik yang utuh atau tidak utuh per jamnya (Yendri, 2014). Dari uji kinerja alat yang telah dilakukan maka didapat kapasitas pengupasan alat sebagai berikut.

Jumlah kelapa terkupas

Total waktup pengupasan

Total waktu pengupasan per jam

$$
\begin{aligned}
\text { Kapasitas pengupasan } & =\frac{\text { Jumlah yang terkupas }(\mathrm{buah})}{\text { Waktu Pengupasan }(\mathrm{jam})} \\
& =\frac{3 \mathrm{buah}}{0,17 \mathrm{jam}}=17 \mathrm{buah} / \mathrm{jam}
\end{aligned}
$$

Torsi

Adalah besar satuan gaya pada gear pendorong untuk menekan tempurung kelapa ke arah mata pisau. Dari uji kinerja alat, didapatkan besar torsi sebagai berikut (Yudhistira, 2016) : 


$$
\begin{aligned}
\tau & =\frac{P}{2 \pi\left(\frac{N}{60}\right)} \\
& =\frac{558,75}{2 \times 3,14\left(\frac{19}{60}\right)}=278,41 \mathrm{Nm}
\end{aligned}
$$

\section{Analisa Ekonomi Alat}

Analisa ekonomi teknik yang dilakukan terhadap mesin pengupas tempurung kelapa ini adalah biaya tetap (Fixed cost), biaya tidak tetap (Variabel cost), biaya pokok dan BEP (Melly \& Ernita, 2014).

Asumsi mesin

Harga jual alat (P)

Umur ekonomis alat $(\mathrm{N})$

Harga akhir(S)

Bunga bank (I)

Jam kerja/tahun $(\mathrm{X})$

Jam kerja/hari

Upah operator(Rp)/hari

Jumlah operator

Biaya listrik

Kapasitas

$$
=\operatorname{Rp} 2.971 .020
$$$$
=5 \text { tahun }
$$$$
=10 \% \times \mathrm{P}
$$

$=12 \% /$ tahun

$=2400 \mathrm{jam} / \mathrm{tahun}$

$=8 \mathrm{jam} / \mathrm{hari}$

$=\operatorname{Rp} 80.000 /$ hari/orang

$=1$ orang

$=\mathrm{Rp} 1.480 / \mathrm{KWh}$

$=17$ butir/jam

\section{Biaya tetap (BT)}

Biaya tetap adalah biaya yang dikeluarkan meskipun alat dan mesin tersebut tidak digunakan, dimana biaya ini bersifat independen terhadap pemakaian alat dan mesin. Komponen biaya tetap untuk mesin pengupas tempurung kelapa terdiri dari biaya penyusutan dan bunga modal.

Biaya penyusutan (D)

$\mathrm{D}=\mathrm{P}-\mathrm{S} / \mathrm{N}=\underline{\text { Harga awal }- \text { harga akhir }}=\underline{\mathrm{Rp} 2.971 .020-\mathrm{Rp} 297.102}=\mathrm{Rp} .534 .783 /$ tahun

Bunga modal (I)

$$
\text { Umur ekonomis alat } 5 \text { Tahun }
$$

$\mathrm{I}=\frac{\mathrm{i}(\mathrm{P})(\mathrm{n}+1)}{2 \mathrm{n}}=\frac{0.12(\mathrm{Rp} 2.971 .020)(5+1)}{2 \times 5}=\mathrm{Rp} 213.913 /$ Tahun

Biaya tetap $(\mathrm{BT})=$ Biaya penyusutan $(\mathrm{D})+$ Bunga modal $(\mathrm{I})$

$$
=(\operatorname{Rp} .534 .783+\operatorname{Rp} 213.913)=\operatorname{Rp} 748.696 / \text { tahun }
$$

\section{Biaya tidak tetap (BTT)}

Biaya tidak tetap adalah biaya yang dikeluarkan tergantung sedikit atau banyaknya alat dan mesin dioperasikan. Biaya ini sangat dipengaruhi oleh jam pemakaian alat. Biaya tidak 
tetap untuk mesin pengupas tempurung kelapa terdiri dari upah operator, biaya perawatan dan biaya listrik.

Upah Operator $=\underline{\operatorname{Upah}(\mathrm{Rp}) / \text { hari } \mathrm{x} \text { jumlah operator }}$ Jam kerja/ hari

$$
=\frac{\operatorname{Rp~} 80.000,-\mathrm{x} 1 \text { orang }}{8 \mathrm{jam} / \text { hari }}=\operatorname{Rp~10.000/\mathrm {jam}}
$$

Biaya perawatan $=\underline{1.2 \% \times(\mathrm{P}-\mathrm{S})}$

$100 \mathrm{jam}$

$$
=\frac{0.012 \times(\operatorname{Rp} 2.971 .020-\mathrm{Rp} 297.102)}{100 \mathrm{Jam}}=\mathrm{Rp} \mathrm{320,87-/ \textrm {Jam }}
$$

Biaya listrik = Daya motor $3 / 4$ HP $\mathrm{x}$ biaya listrik $/$ jam

$$
=0.55 \mathrm{kw} \times \mathrm{Rp} 1.480 / \mathrm{Kwh}=\mathrm{Rp} 827 / \mathrm{jam}
$$

Biaya tidak tetap $(\mathrm{BTT})=$ Upah operator + Biaya perawatan + Biaya listrik

$$
=(\operatorname{Rp} 10.000+\operatorname{Rp} 320,87+\operatorname{Rp} 827 / \mathrm{KWh})=\mathrm{Rp} 11.147,87 / \mathrm{Jam}
$$

\section{Biaya pokok (BP)}

Biaya pokok adalah biaya yang diperlukan oleh suatu mesin untuk setiap unit produksi. Rumus biaya pokok sebagai berikut :

Biaya pokok $(B P)=\frac{\frac{B T}{x}+B T T}{C}$

$$
=\frac{\frac{\mathrm{Rp} 748.696 / \text { tahun }}{2400 \mathrm{jam}}+\mathrm{Rp} 11.147,87 / \mathrm{Jam}}{17 \mathrm{buah} / \mathrm{jam}}=R p 674,10 / \mathrm{buah}
$$

\section{Break event point (BEP)}

Break event point (BEP) adalah keadaan alat atau mesin yang dihasilkan tanpa keuntungan maupun rugi. Jumlah pendapatan sama besarnya dengan jumlah biaya. Analisa ini mempelajari pengaruh timbal balik antara pendapatan, biaya dan keuntungan. Rumus BEP yaitu :

$$
\begin{aligned}
B E P & =\frac{B T}{R-\left(\frac{B T T}{C}\right)} \\
& =\frac{\operatorname{Rp~} 748.696 / \text { tahun }}{R p 800 / \text { buah }-\left(\frac{\text { Rp 11.147,87 } / \mathrm{jam}}{17 \text { buah } / \mathrm{jam}}\right)}=5.190 \mathrm{buah} / \text { tahun }
\end{aligned}
$$

\section{Kesimpulan}

Mesin pengupas tempurung kelapa memiliki spesifikasi tinggi $116 \mathrm{~cm}$, lebar $50 \mathrm{~cm}$, panjang $60 \mathrm{~cm}$, jumlah gigi pendorong $22 \mathrm{~T}$, jumlah gear pendorong $2 \mathrm{buah}$, dan mata pisau dari HSS. Dari pengujian kinerja mesin pengupas tempurung kelapa didapatkan kapasitas 17 
buah/jam, kecepatan input speed reducer 560 RPM, kecepatan output speed reducer 19 RPM dan torsinya $278.41 \mathrm{Nm}$. Analisa ekonomi mesin tersebut dengan biaya tetap sebesar Rp 748.696 /tahun, biaya tidak tetap Rp 11.147,87/jam, biaya pokok Rp. 674.10/buah dan BEP (Break Event Point) 5.190 buah/tahun.

Hal-hal yang perlu diperhatikan untuk perbaikan mesin ini kedepan adalah : Mata gear pendorong sebaiknya diganti dengan mata gear yang melengkung dan berlawanan arah jarum jam agar lebih menekan. Ukuran diameter gear pendorong sebaiknya lebih besar. Diameter pulley yang digunakan pada input speed reducer sebaiknya berukuran lebih besar. Ukuran diameter dan kelengkungan mata pisau masih perlu diperhatikan dan dikaji lebih lanjut. Sistem transmisi sebaiknya diberi pelindung untuk meminimalisasi kecelakaan kerja. Rantai dan gear sebaiknya diberi pelumas setiap kali pemakaian.

\section{Daftar Pustaka}

Cristianti, L \& Prakosa, A. H. (2009). Pembuatan Minyak Kelapa Murni (Virgin Coconut Oil) Menggunakan Fermentasi Ragi Tempe. [Laporan Tugas Akhir] : Surakarta : Universitas Sebelas Maret.

Djatmiko, B. \& Widjaja, A.P. (1985). Minyak dan Lemak. Bogor : Institut Pertanian Bogor. Mahmud, Z \& Ferry Y. (2005). Prospek Pengolahan Hasil Samping Buah Kelapa. Perpektif. $4(2): 55-63$.

Melly, S. \& Ernita, Y. (2014). Ekonomi Teknik. Payakumbuh : Politeknik Pertanian Negeri Payakumbuh.

Palungkun, R. (2001). Aneka Produk Olahan Kelapa. Jakarta : Penebar Swadaya.

Sulaeman \& Rusyadi, M. (2013). Analisa Efisiensi Rooftop Solar Copra Dryer Dengan Susunan Kolektor Secara Seri. Institut Teknologi Padang. Jurnal Teknik Mesin. 3 (2) : $70-77$.

Warisno. (2003). Budi Daya Kelapa Genjah. Yogyakarta : Kanisius.

Woodroof, J.G. (1978). Coconut : Production, Processing, Product. Second ed. West Port. Connecticut. USA : The AVI Publishing Company Inc.

Yudistira. (2016). Pendidikan Mekanik. Payakumbuh : Politeknik Pertanian Negeri Payakumbuh.

Yendri, D. (2014). Modifikasi Dan Uji Kinerja Mesin Perajang Ubi Kayu Untuk Meninggkatkan Kapasitas Produksi Industri Rumah Tangga. Payakumbuh 